\title{
Supporting and Inhibiting Factors on the Implementation of the Master Plan Activities in Serayu River Voyage (SRV) Within the Framework of Tourism Development in Banyumas Regency
}

\author{
Imam Pamungkas* , Agus Suryono, Sarwono \\ Master Program of Public Administration, Faculty of Administrative Sciences, University of Brawijaya, Malang, Indonesia
}

\begin{abstract}
The Master Plan Activity of Serayu River Voyage (SRV) for tourism development in Banyumas Regency were expected to be completed within five years from 2008 to 2012, but during the period until 2013, most programs and activities have not been implemented. The results showed that the Master Plan of SRV in the framework of tourism development in Banyumas Regency has not been implemented properly. The cause is the absence of good coordination between agencies, the lack programs and activities integration, supporting documents have not been revised, absence of good socialization, and the lack of private sector contribution. The factors that constrain and support implementation of the Master Plan is described as follows. Supporting factors: competent human resources (implementor) already available at the managerial level and have intellectual tourism, it is only need to add personnel in the sector of culture; the availability of adequate budget; institutions that have been effective and efficient; High community response; High commitment of Banyumas Regent and cooperation related parties (stakeholders); and natural conditions of Serayu tend to calm and the river slope condition is small. The constrain factors: regulatory policies; integration of programs and activities; coordination and socialization implied sectoral ego that need to be addressed.
\end{abstract}

Keywords: implementation, master plan, Serayu River Voyage, human resources, regulation

\section{INTRODUCTION}

The flow of Serayu River that crosses Banyumas Regency has relative flat topography and mountains with the slope between $15^{\circ}-45^{\circ}$. As a flow that has approached upstream region, the presence of Serayu River Dam serves for irrigation, drinking water, river controller, flooding controller, inland fisheries, and recreation. The last function of Serayu River Dam is as a mean of recreation that is very possible to be developed in Banyumas.

Implementing activities on Master Plan of Serayu River Voyage (SRV) in the Framework of Tourism Development in Banyumas is still partial. It was not well structured and implemented by sectoral trend and showed no active role of stakeholders. The implementation of SRV Master Plan is expected to be a new tourist destination, but it has not been implemented according to the expectations of society and local government. The assumption occur by causative factors including: lack of coordination between stakeholders in the region, limited human resources, institutional which has not been maximum, and regulations which still need to be revised. There has not been a redesign to

\footnotetext{
${ }^{*}$ Correspondence address:

Imam Pamungkas

Email : imam_pamungkas17@yahoo.co.id

Address : Master Program of Public Administration, University of Brawijaya, Jl. Veteran. Malang 65145.
}

accommodate all of the planned activities. It has no environmental documents and the role of the private sector is still lacking.

In accordance with the Indonesian Government Regulation No. 6 of 2006 on the Management of State/Region Property, the utilization of state property in the form of land implemented by the management of goods. The aimed goods manager is the Minister of Finance, because the land belongs to the central government.

According to Hadinoto [1], land in the tourism development program is the most critical resource to be managed. Land with incorrect use can cause damage and great loss for tourism. The use of land gives a creative challenge and it is open to error and loss in tourism development. In the planning and development of a tourism program, planning and use of land could be the most important responsibility. While the evaluation criteria of management regarding the necessity and suitability of land for tourism development includes: location; scenery; environmental suitability; topography; availability; and area that can be used.

The role of land in the management of tourism development is a major factor and act as a priority to be managed, so that the provision and land use should have clear status on the land. While the facilities and infrastructure are: 
airports; terminals; ports; railway stations; telecommu-nications; road network, etc [2].

One of the most important component in tourism activity is the accessibility or the smooth transfer of a person from one place to another; movement at close range, intermediate, and far. Thus it needs transportation tools [3]. Land resources for transportation also becomes an integral part which is needed for good planning of land resource.

Development of land resources also facing the problem lack of harmony between the various interests and various sectors of the economy; which in turn will not support each other. This situation will be worsen again by a careless land resource management system.

Hadinoto [1] stated that aspects included in the conceptual planning stage is the selection of tourism land, the allocation of land use, and super-vision on the land users, as well as its budget.

Fennel in Pitana and Diarta [4] mentioned that the natural resources can be developed into a tourism resource is water. Water holds a very important role in determining the type and level of outdoor recreation, could be developed into other type of tourism sucha as beach/nautical, lakes, rivers, and others (sailing, cruises, fishing, snorkeling).

According to Hakim [5], the term of sustainable tourism is the balance between tourism and economic development, environmental protect-ion. Satisfaction between the two parties (i.e. tourists and local communities) are the main ideas in interpreting sustainable tourism. Hunter in Hakim [5] stated it is easy to discuss sustainability, implementation is the problem. It is frequently appears in the discourse and discussion of sustain-able development, including the tourism industry. Mihalic in Hakim [5] stated that the quality of the environment includes the quality of landscape or natural scenery itself, whose quality may decline due to the activity human beings.

Natural resources such as water and rivers, especially in the Master Plan Activity of Serayu River Voyage (SRV) in Banyumas, can be developed as a tourism resource and tourist destination. The development of natural resources should be balance between economic sectors and environmental protection. It should also always be maintained properly thus the quality will not decline as human activity and tourism itself.
The purpose of the research on the implementation of Master Plan Activity of Serayu River Voyage (SRV) in the framework of tourism development in Banyumas are assessing the contents of the Master Plan Activity of Serayu River Voyage (SRV) which will be implemented, the implementation of the Master Plan Activity of Serayu River Voyage (SRV) and analyze the factors that inhibit and support the implementation of Master Plan Activity Serayu River Voyage (SRV).

\section{RESEARCH METHODS}

\section{Research Focus}

The study focused on the factors that inhibit and support the implementation of the Master Plan of Activity of Serayu River Voyage (SRV). It includes supporting and inhibiting factors, internal and external.

\section{Research Site}

The study located in the Regency of Banyumas, with research site in the Department of Youth, Sport and Tourism of Banyumas and in some Local Work Unit (SKPDs) related to the object of research.

\section{Data Collection}

This stage was conducted by getting deeper personal relationships and more harmonious with various respondent/resources; in expectation for getting accurate and relevant data or information. Personal relationships are also useful to grow self-confidence and credibility of the researcher. Persuasive interpersonal communication is also needed especially to get highly sensitive information.

The stage to collect data are interview, observation, and documentation. This study used structured and unstructured interviews to develop things that require in-depth information. Observa-tion were assessed directly in the field through the five senses to the phenomenon of the problem, according to the research focus that has been set.

Documentation conducted by collecting and learning various of documentary informationin (documents or archive records) related to the Master Plan Activity of Serayu River Voyage (SRV). Documentation used as a reference material and preliminary data in conducting research and interviews. It also a comparison with the information obtained from the field research and interviews. The documentation include: document of Master Plan Activity of 
Serayu River Voyage (SRV), the applicable regulations of law such as: laws, government regulations, local regulation, regent regulations and other relevant documents.

\section{RESULTS AND DISCUSSION} Internal Supporting Factors

Competent human resources (implementor)

Availability of human resources support on SRV is already abundance, including NGO Association of Serayu Tourism Society (PMPS), community leaders, artists-humanist and also Tourism Awareness Group (Pokdarwis). In accordance with Edwards III [6], there are factors that have a direct and indirect impact on the failure or success of policy implementation, i.e. resources. Resource is in the form of human resources (implementor competence), materials/facilities and financial resources.

Enhancement of human resources at tourism sector need to be facilitated by the Government of Banyumas. The role of government in determining tourism policy is to build and facilitate the improvement of the human resources quality $[4,7]$. It conducted by ensuring the education and professional training to supply the need for labor in the tourism sector. Human resources in the framework of tourism policy implementation run the concern/awareness of society program [4] that contributes positively to the success of tourism.

\section{Availability of Budget}

Regent of Banyumas has expressed a commitment to budgetary policies for activities of SRV. Mill [8] explained that planning process in tourism sector should also consider the planning component that needs fund for the operation. The availability of the budget does not become a serious problem because there is a big commitment from the decision maker for waiting the aspects of legality and licensing.

\section{Institutional}

Department of Youth, Sport, Culture and Tourism in Banyumas has pretty good organizational structure, duties and functions. Similar to Wahab [9], the effectiveness of policy implementation need to meet right executor, the implementation actor is government policy, government or private parties as executor (privati-zation or contract).

Institution is an important factor that have a direct and indirect impact on the failure or success of policy implementation [6], i.e. bureaucratic structure. Bureaucratic structures as the executant organizational structure has a significant influence on policy implementation.

One important aspects on the structure of each organization is the existence of Standard Operating Procedure (SOP). SOP becomes a guidance for the implementor to act. Organizational structure that occupied too long will tend to weaken supervision and lead to red-tape. That is a complicated and complex bureaucratic procedures, which in turn causes the activity of the organization becomes inflexible.

\section{Internal Inhibiting Factors \\ Regulatory policy}

Regulation in the Implementation of Master Plan Activity of SRV such as RPJMD, RIPPDA, and Spatial and Strategic Plan of SKPD has been existed. It is in line with Mill [8] that in the planning process of tourism sector should also consider the planning component, e.g. legal environment, specific laws and regulations for a tourist destination that should be known.

Another theory in the framework of tourism policy implementation, especially regulation and supervision [4]. Things that have to be implemented is building legislation and regulatory mechanisms to encourage the development of tourism. It conducted through the support of national tourism organizations, travel agent, accommodation and other sectors in the tourism.

Meanwhile, the role of government in determining tourism policy is strategic and responsible [4,7]. Government should provide and facilitate the needs of legislation, regulation, and control that are applied in tourism, environmental protection, and preservation of culture and heritage.

\section{External Supporting Factors \\ Public Response}

Activity of SRV in the Framework of Tourism Development in Banyumas has a very good response by the community. The Law No. 25 of 2004 on National Development Planning System (SPPN) mentioned that the purpose and principal function of development planning is to optimize community participation in development planning.

Implementation in framework of tourism policy made a social audit [4] in terms of how the local community, villagers and the surrounding commu-nities affected by the tourism. 
Natural conditions and weather factors

Natural conditions and the weather is very supportive as a supporting factor for the activities of SRV. Liu in Pitana and Diarta [4] stated that the conditions and the uniqueness of the environ-ment, flora and fauna is often act as key attraction for tourism. Water resources has a very vital role in supporting the development of tourism.

\section{Policy Makers Commitment}

The Regent of Banyumas shows a high commitment to the implementation of the Master Plan Activity of SRV in the Framework of Tourism Development in Banyumas. Darwin [10] explained one aspect that determine the level of public policy implementability is the affected nature of the attraction.

A policy implementation process will lead to a conflict of targeted groups or community. It means there is an open opportunity for the emergence of certain advantaged groups (gainer), while on the other hand implementation of the policy disserves other groups/looser [11]. These commitment of policy makers in local government becomes the factors that support the implementation of the Master Plan Activity of SRV in the Framework of Tourism Development in Banyumas.

\section{Related Parties Cooperation (Stakeholders)}

Cooperation with relevant parties in the implementation on the Master Plan Activity of SRV has been existed, although still in initial stage. Cooperation with stakeholders is needed in the implementation of the policy as explained by Mazmanian and Sabatier in Dwijowijoto [11]. The policy's ability to structure the implementation process is hierarchical integration among implementing agencies. Meanwhile, Meter and Horn in Dwijowijoto [11] stated the variable that influences public policy is the implementation and communication activities between organizations. In addition, tourism management requires consultation with all stakeholders $[4,7]$. The cooperation with related parties (stakeholders) is also supporting factors for the implementation of Master Plan Activity of SRV.

\section{External Inhibiting Factors}

The integration of programs and activities

Less coherence on the Activity of SRV with other policies needs to be addressed thus the implementation activities of SRV will goes well.
Dwijowijoto [11] mentioned the needs for clear and consistency purpose, accuracy of financial resource allocation and hierarchical integration among implementing agencies. The integration of programs and activities become the factors that inhibit the implementation of the Master Plan Activity of SRV.

\section{Coordination and socialization}

Coordination and socialization in the Master Plan Implementation Activity Serayu River Voyage (SRV) is still not good as a result of sectoral ego created among related local government offices.

The constraint is in accordance with the opinion of Darwin [10], which explains that the an aspect that determine the implemental level of public policy is the nature of interest which affected. A process of policy implementation will lead to a conflict of target groups or communities. It means there is an open opportunity for the emergence of certain advantaged groups (gainer), while on the other hand implementation of the policy disserves other groups (looser) [12].

Hoogwood and Gun suggested that the implementation of policies needs necessary conditions of communication and perfect coordination [13]. Communication is the glue of organization, and coordination is the origin of teamwork and synergy formation. The lack of coordination and socialization including factors that inhibit the implementation of Master Plan Activity of SRV.

\section{SWOT Analysis}

Strength

a. Serayu River Voyage (SRV) is potential to develop water recreation, land recreation, cultural recreation, and educational recreation.

b. The need of green open space as requirements of Serayu River Voyage activity can be maintain.

c. Accessibility (in the form of a path) to the location of Serayu River Voyage has been well available.

d. Institutions by the Department of Youth, Sports, Culture and Tourism in Banyumas.

e. Regulations and policies in the planning of Master Plan, the Regional Regulation, Strategic Planning and Medium Term Development Plan (RPJMD).

\section{Weakness}

a. Low Competent of Human Resources. 
b. Potential land in the border/riverbanks of Serayu.

c. Land for Green Open Space has not been dominated by the Government of Banyumas.

d. Accessibility to the location still need regular maintenance.

e. Rules and policies are still not properly implemented.

f. Different understanding on the rules and policies.

\section{Opportunities}

a. Having cooperation prospect with private parties (investor).

b. Cooperation of provincial governments and central government.

c. Land leasing system by Banyumas Regency from Central Government.

d. Improvement on human resources and procurement of employees

e. The same perception on rules and policies.

\section{Threats}

a. SRV has risk of flooding and natural disasters.

b. Need a substantial budget for maintenance.

c. Threaten ecosystems and environmental damage, especially on the rivers and riverbanks, etc.

d. Threaten the social and cultural life of society and local knowledge (local wisdom).

e. The existance of regulation and legislation policies should be evaluated as a supporting activity of Serayu River Voyage (SRV)

\section{RECOMMENDATION}

Based on the conclusions, we recommend some of the following:

1. The policy for the implementer in the creation of programs and activities that support Serayu River Voyage should meet program targets and activities of SRV.

2. Improving the design of tourism cooperation to expand and improve the potential network marketing/promotion of tourism, especially SRV activities in order to develop tourism in Banyumas.

3. Improving the policy in the Master Plan Activity of SRV by revising the master plan design completed by coordinate geographic points of SRV activities' location (digital map) and determines the locus of land utilization or the overall need of SRV land.
4. Construct environmental document as in the form of Environment Impact Assessment (AMDAL) that includes integrated activities in SRV footprint; in accordance with Regulation of the Minister of Environment No. 5 of 2012, protected areas and tourism areas should have documents on the environment.

5. Preparation of Detailed Spatial Plan which contains and sets the space design and space utilization for the Implementation Activity of SRV. Certainty of the law is a reference for each businessmen, tourism stakeholders and public to partici-pate in SRV activities.

6. Revision of Regional Tourism Development Master Plan, because it has not been implemented properly and needs to be adjusted to the Regional Regulation on Spatial Planning of Banyumas Region Year 2011-2031.

7. Applying for the permition on the use of Serayu River channel and on lands at the edge or border of Serayu River.

8. Conceptualization of cooperation pattern with the central government in the utilization and use of land owned by the central government that is located along the banks of Serayu River or in the water border areas. The cooperation could use a lease system.

9. The addition of employees with specific competencies with Employment Agreement (P3K) which is suitable with regulation No. 5 of 2014 on Civil Administrative State. Apparatus competencies can be enhanced through various technical training and workshops.

10. Implementing publication, socialization, public hearing and promotion through printed, electronic and other information media such as social networking. Socialization and this publication should be conveyed to the bottom of society through public institutions.

11. Making data and information systems by establishing data and information systems of tourism integrally to ensure operational continuity and also functioned as market information.

12. Increase the budget and determination the priority scale in the Implementation of Master Plan Activity of SRV.

13. Priorities determination in the development of Serayu River thus no overlap utilization of river channel on Serayu River Dam. 
14. Finalization of the Master Plan Activity of SRV Period 2015 as follows:

a. Revision of construction design

b. Making environmental document

c. Development of roads and infrastructure

d. Arrangement of Detailed Spatial Plan

15. Finalization of the Master Plan Activity of SRV Period 2016:

a. Licensing on the use of land border and Serayu River channel

b. Drafting a pattern of cooperation

c. Drafting the revision design of Regional Tourism Development Master Plan

16. Finalization of the Master Plan Activity of SRV Period 2017 includes:

a. Physical construction on Phase I of Dock I SRV in the location of Serayu River Dam

b. Addition and improvement of human resources in tourism

c. Implementation of cooperation design

d. Physical Development Phase II Dock I SRV in the location of Serayu River Dam

e. Physical Development of Dock II SRV in the Location of Pegalongan Village, SubDistrict of Patikraja

17. Finalization of the Master Plan Activity of SRV Period 2018 includes:

a. Physical Development of Dock IV SRV in the Location of Petir Village, Sub-District of Patikraja

b. Socializations and publications

c. Physical Development of Dock III SRV in the Location of Kaliori Village, Subdistrict of Kalibagor

d. Design travel packages

e. Making the system of Regional Tourism on Development Implementation

\section{REFERENCES}

[1] Hadinoto, K. 1996. Development planning of tourism destination. UI-Press. Jakarta. p. 79.

[2] Yoeti, O.A. 1994. Introduction to tourism knowledge. Angkasa. Bandung.

[3] Sammeng, A.M. 2001. Tourism horizon. Balai Pustaka. Jakarta.

[4] Pitana, I G., and Diarta, I K.S. 2009. Introduction to tourism. Andi Publisher. Yogyakarta. 88-114.

[5] Hakim, L. 2004. Fundamental ecotourism. Bayumedia Publishing. Malang. 11-116.

[6] Edwards III. 1980. Implementing public policy. Congressional. Quarterly Press, Washington.
[7] WTO. 1980. Social and cultural impact of tourism movement. World Tourism Organiza-tion. Madrid.

[8] Mill, R. C. 2000. Tourism, the international business. Sastrio, T. B. (Transl.). Raja Grafindo Persada. Jakarta.

[9] Wahab, S. 1992. Tourism Management. Gromang, F. (Transl.). Pradnya Paramita. Jakarta. p. 137-139.

[10] Darwin. 2002. Good Governance and public policy. Seminar of Realizing Good Governance as State Democracy Agenda. NGO Forum of Yogyakarta Special Region. September $30^{\text {th }} 2002$, Yogyakarta.

[11] Dwidjowijoto, R. N. 2006. Public policy for developing country, formulated models, implementation and evaluation. Elex Media Komputindo. Jakarta.

[12] Dwiyanto, A. 2000. Reform of governance and regional autonomy. Center of Population Studies and Policy. Gadjah Mada University. Yogyakarta.

[13] Hoogwood and Gunn. 1986. Policy analysis for the real world. Oxford University Press. London. 